DOI https://doi.org/10.18551/rjoas.2017-12.42

\title{
LIFE OF THE RIVERINE FISHERMEN: PRESENT STATUS OF LIVELIHOOD STRATEGIES AND ECONOMIC CONDITIONS AT PAYRA RIVER, BANGLADESH
}

\author{
Rahman Md. Hafijur, Haque Md. Mahfuzul \\ Department of Fisheries Management, Bangladesh Agricultural University, \\ Mymensingh, Bangladesh
}

\author{
Mithun Paul* \\ Marine and Coastal Resources Institute, Prince of Songkla University, Songkhla, Thailand
}

\author{
Hossain Md. Moazzem \\ Department of Fisheries Management, Patuakhali Science and Technology University, \\ Patuakhali, Bangladesh \\ Hasan Md. Rakib \\ Department of Fisheries, Ministry of Fisheries and Livestock, Bangladesh. \\ *E-mail: mithunpstu007@gmail.com
}

\begin{abstract}
A study was conducted to find out the livelihood condition of Payra River, located at the Angaria union of Dumki upazila under the district of Patuakhali for twelve months from July, 2012 to June, 2013. In the present study, it was found that highest percentage $(40 \%)$ of the fishermen is young (21 to 31 years) where about $92 \%$ of the fishermen used boat for fishing. By religion, $46 \%$ fishermen are Muslims and majority (54\%) fishermen are Hindus. In terms of education, $50 \%$ had education up to primary level, $12 \%$ of fishermen in secondary level, $4 \%$ fishermen had education up to SSC level and $6 \%$ had no education. About $54 \%$ of the fishermen are dependent on upazila health complex for health facilities. Maximum housing condition of the fishermen are Earthen made (52\%), $44 \%$ are Tin shed building and only $4 \%$ are fully furnished cemented building. Service and labor are the main occupation of $4 \%$ fishermen. Majority (80\%) of fishermen main income source is fishing and among them $54 \%$ of the fishermen had 1 to 10 decimal homestead lands and majority $(72 \%)$ of the fishermen had no agricultural land. In case of other occupation $28 \%$ fishermen are involved in agriculture as other occupation, $40 \%$ fishermen in day laborer, $8 \%$ fishermen in business and $2 \%$ fishermen in service. The average monthly income was found to be Tk. 15000 when agriculture is the main occupation. When fishing is the main occupation the monthly income is Tk. 10410. It has been observed that $54 \%$ fishermen have training on one or more than one related matter, $46 \%$ have no training. So from this study, we can conclude that the livelihood statuses of the riverine fishermen of Payra River were not satisfactory and the fishermen were deprived of many amenities.
\end{abstract}

\section{KEY WORDS}

Payra River, livelihood strategies, riverine fishermen, economic conditions.

According to FAO, Bangladesh is one of the world's most important inland fishing nations. Fish contribution national GDP and agricultural GDP is $3.69 \%$ and $23.12 \%$, respectively (Department of Fisheries Report, 2015). Total employment in fisheries sector is for 17.80 million people (11\% of total population) and in woman employment in fisheries sector is 1.40 million (8.49\% of fisheries sector employment) (Department of Fisheries Report, 2015). But, still fishermen are one of the most vulnerable communities in Bangladesh. The livelihood statuses of these fishermen are not satisfactory; availability of fishes in the river is also declining day by day (Mahmud et al., 2015). Most of them are live 
from hand to mouth (Ali et al., 2014). Hossain et. al., 2015 stated that fishermen are traditionally poor and fishing is considered as a low-class profession in Bangladesh.

The most critically and sensitive areas for open water aquaculture in Bangladesh is south western coastal area which supplies both fresh water and salt water indigenous fishes (IUCN, 2003). Payra River is a body of running water moving to a lower level in a channel on land in the country of Bangladesh and the river finally falls into the Bay of Bengal by the name of Burishwar River (Islam et al., 2015). This river is an exclusive aquatic ecosystem with diversified species of plants, fish and other organisms and most of the catch of this river is landed by small-scale local fishermen (Islam et al., 2015). This area of the river consisting of fishery plays a very important role in the alleviation of rural poverty and supplying food to the poor fishing community (Mahmud et al., 2015).

The vast majority of the fishing communities of Bangladesh are confronting more or less similar problems that standing the way of increasing catch and hence income from fishing operations and fishermen are one of the most vulnerable communities by any standard and over the years (Hossain et al., 2013). Alam and Bashar (1995) estimated the average per capital annual income of the fishermen families to be BDT 2,442 i.e. about $70 \%$ lower than the per capital income of the country as a whole. Being an isolated community fishermen are deprived of many amenities of life. Pollnac (1991) has reported that the relationship between technology and social organization in small-scale fishing communities was regarded as providing the essential contest for the institutional system, where the poor would be helped by equipment's and new technology. For this aim, investigation of social patterns, economic system and some related aspects of the fishermen are to be found as the basic need. So, this study was conducted to evaluate the living condition of fisherman near Payra River to find out their standard of living.

\section{METHODS OF RESEARCH}

This study was conducted to find out the fisheries of Payra River, Patuakhali, Bangladesh for 12 months from July, 2012 to June, 2013. The study was based on collection of primary and secondary data. Firstly, a pretesting questionnaire was developed keeping in view the objectives of the study, then a final questionnaire was then developed in logical sequence so that the fishermen could answer chronologically. According to the experience gained in pre-testing, the final questionnaire was improved, rearranged and modified. Secondly, Primary data were collected through personal interview complemented by multiple methodological Participatory Research Approach (PRA) tools such as Focus Group Discussion (FGD) and Crosscheck Interviews (Cl) with key informants namely Sub-district Fisheries Officer (UFO), AFO, and relevant NGO workers for the confirmation of relevant information. FGD sessions usually were held at river bank or in a tea stall and $\mathrm{Cl}$ of respondents were conducted in their office. After collection of data, these were edited and coded. All the collected data were summarized and scrutinized carefully and recorded. Then, finally all of the data were analyzed by using certain statistical tool in the Microsoft Excel.

\section{RESULTS AND DISCUSSION}

Human capital. The age structure of the riverine fishermen in Payra River was examined. They are divided into five age groups: 10 to 20 years, 21 to 31 years, 32 to 42 years, 43 to 53 years and above 54 years. The fishermen in the present study are mostly 21 to 31 years (40\%) and 32 to 42 years group (30\%) who could afford much energy and labor in catching fish. There were no under aged fishermen found during this study. Rabbani (2007) recorded age group of $25-50$ years was highest $(46.67 \%)$ and more than 50 years were the lowest $(25 \%)$ of the riverine fishermen in the Karatoa river, which is not similar to the present findings.

In the present study, $46 \%$ fishermen are Muslims and majority $54 \%$ fishermen are Hindus. Rabbani (2007) reported that about $86.67 \%$ and $13.33 \%$ riverine fishermen are Hindus and Muslims respectively. Mahmud (2007) stated that the highest (74\%) number of 
fishermen were from Muslim community where as only $26 \%$ were from Hindu community. Muslim is coming to this profession in an increasing number through breaking the previous norms and value of the society which are due to the economic hardship and lack of employment scope in other sectors.

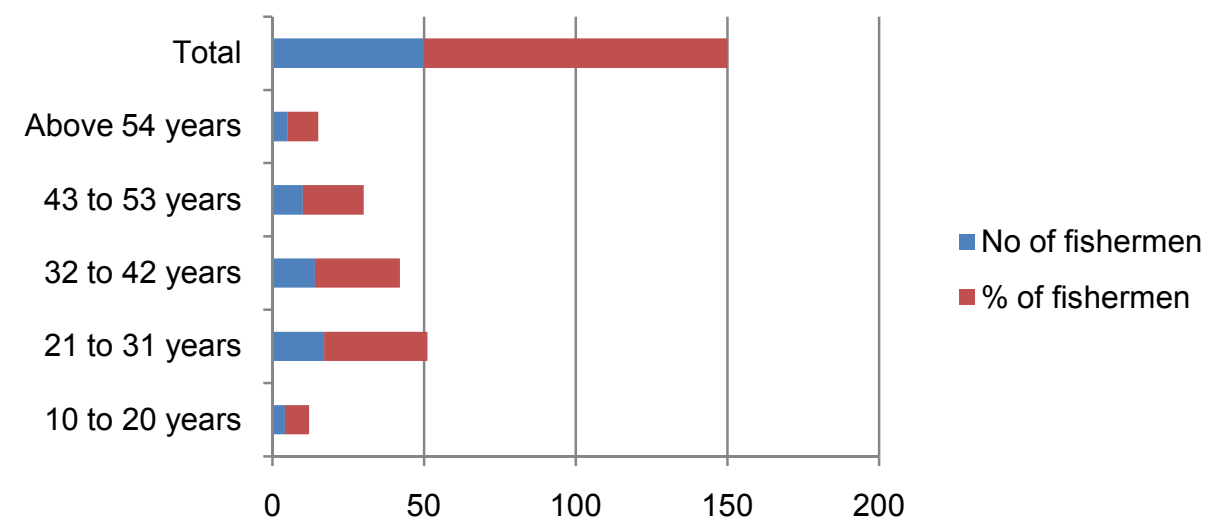

Figure 1 - Age distribution of riverine fisherman in the Payra River in the southern Bangladesh

Human resource developments are largely a function of education. In this present study, it was found that $6 \%$ fisherman had no education, $28 \%$ were capable to write name, $50 \%$ fishermen had education up to primary level, $12 \%$ Secondary (up to 8 classes) level and only $4 \%$ of fishermen had education up to SSC (10 class pass) level. The highest members of fishermen $(50 \%)$ with primary level education were a remarkable feature for the fishing community in the Payra river system. Shahjahan (2000) reported that $63.33 \%$ of riverine fishermen were illiterate, $31.67 \%$ had up to primary level of education and $5 \%$ of riverine fishermen had only secondary level of education in the Jamuna River. Rabbani (2007) reported that $20 \%$ of riverine fishermen were illiterate, $71.67 \%$ of riverine fishermen were up to primary level of education and $8.33 \%$ riverine fishermen had only secondary level of education.

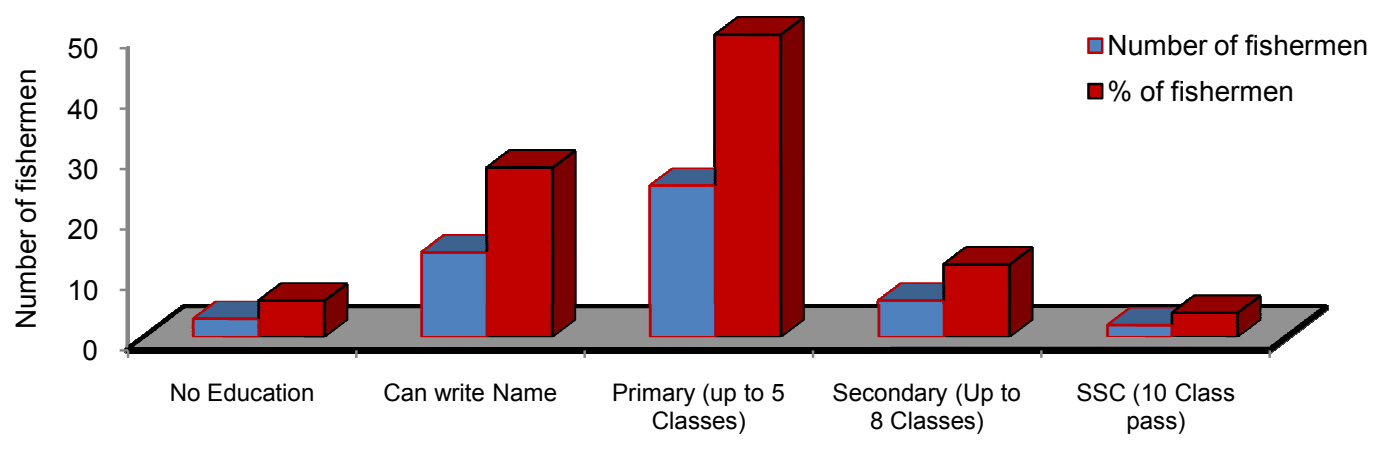

Figure 2 - Educational status of riverine fishermen of the Payra River

In this study, we revealed that $54 \%$ fishermen have training on one or more than one related matter, $46 \%$ have no training. Hossain (2012) reported that $80 \%$ of fishermen, considering all gears were not received any training where as $20 \%$ had training experience in the river system of the Purnavaba River.

A family was defined as the total number of persons living together and taking meals from the same house. The family size and composition are related to income. The study reveals that $48 \%$ of the fishermen had 2 to 5 persons group, $48 \%$ had 6 to 9 persons group and $4 \%$ having more than 10 persons group in their families. Haider (2002) recorded the largest family size (6.67 persons) in Cast net fishermen and smallest family size (4.50 
persons) in hogra fishermen of Doba beel. Miah (2004) recorded the largest and the smallest family sizes of Zolkor beel fishermen in Cast net (5.67 persons) and in thela jal (4.15 persons) respectively.
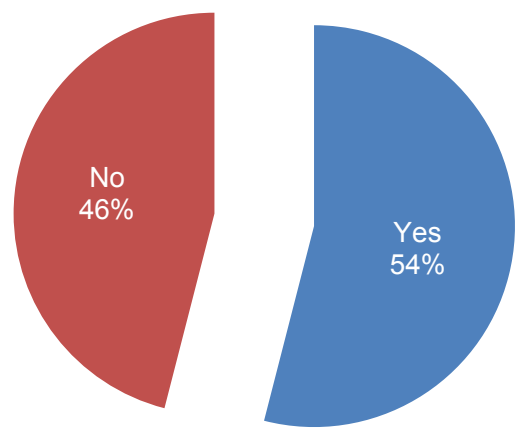

Figure 3 - Receive any training facilities in the riverine fishermen

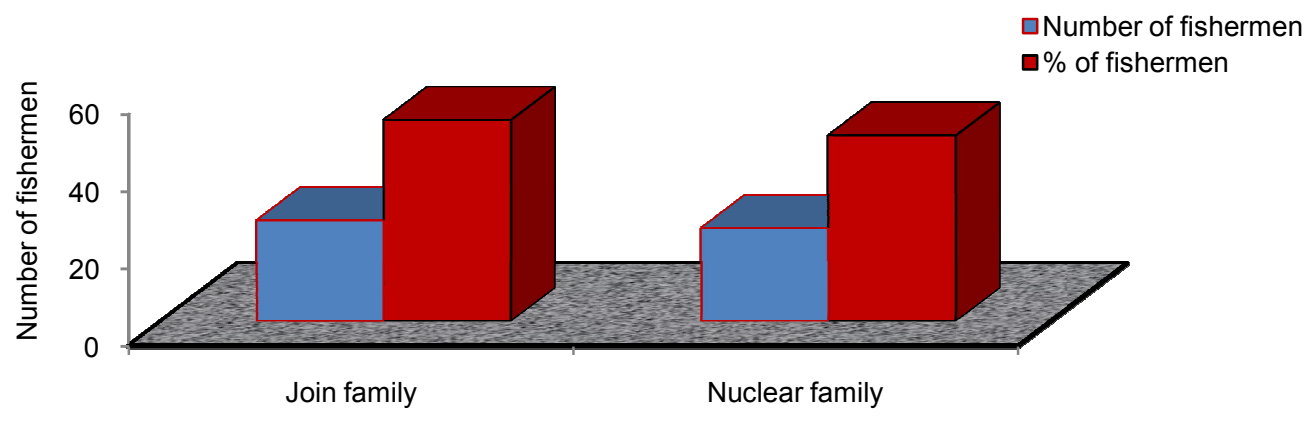

Figure 4 - Family size of riverine fishermen family

In the present study, it was found that majorities (80\%) of the fishermen are married and remain $20 \%$ of fishermen are unmarried. Hossain (2012) found $70 \%$ of the fishermen are married and $30 \%$ of fishermen are unmarried.

Natural Capital. It was found that only $28 \%$ of fishermen had agricultural land and majority $(72 \%)$ of fishermen had no agricultural land. Agriculture is the second occupation in most of the fishermen but lack of agricultural land they choose others.

Most of the rural household family used pond water for cooking, bathing, washing clothes. It was found that only $36 \%$ of fishermen family had pond. The majority $(64 \%)$ of fishermen family had no pond they used neighbor's pond water. Sometimes fishermen family used river water for household activities.

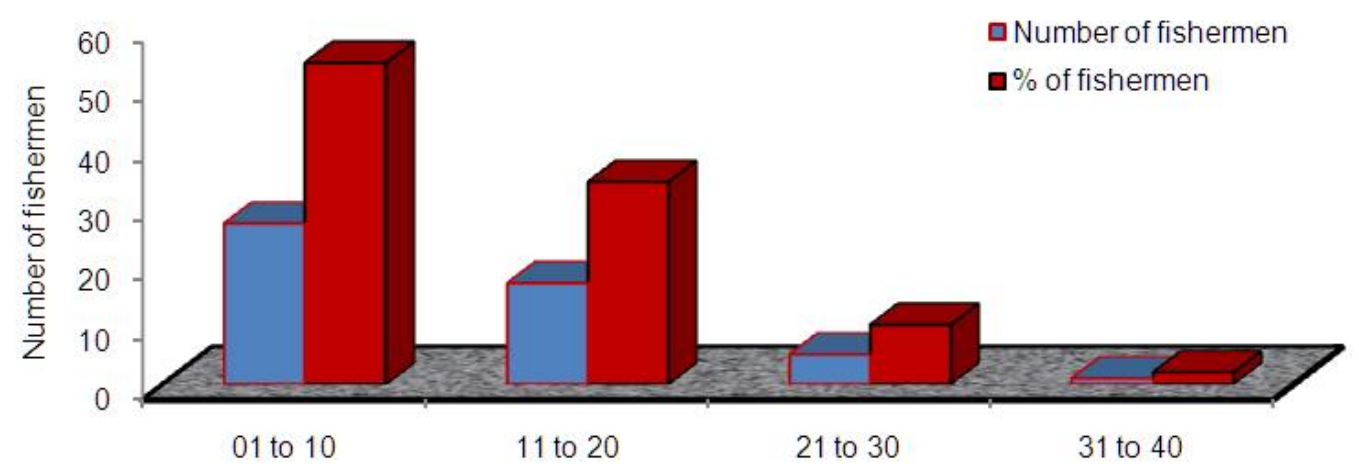

Figure 6 - Homestead status of riverine fishermen of the Payra river 
This study found that $54 \%$ of the fishermen had 1 to 10 decimal homestead land, $34 \%$ had 11 to 20 decimal, $10 \%$ had 21 to 30 decimal and only $2 \%$ fishermen had 31 to 40 decimal homestead lands for living. Homestead areas are important key measure to identify other source of family income. Women or children rear chicken, duck, got, cattle etc. and support family income.

It was found that $82 \%$ of fishermen spend all time for fishing, but $18 \%$ of fishermen catching fish in part time. Most of the professional fishermen spend full time to catch fish but subsistence fishermen spend part time for catching fish. Rabbani (2007) observed that $70 \%$ of fishermen spend full time and $30 \%$ of fishermen catching fish in part-time.

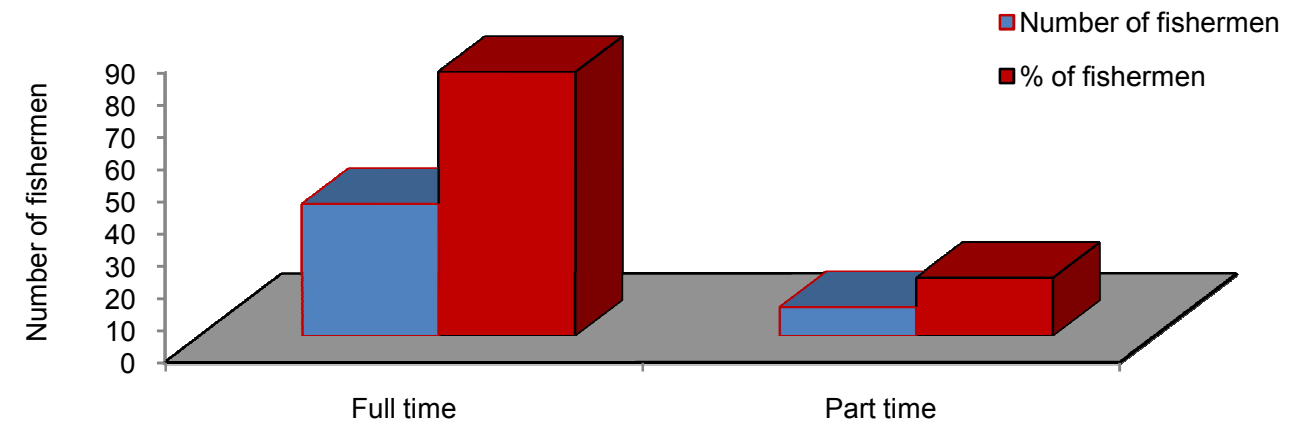

Figure 7 - Fishermen spend time for fishing in the Payra River

Physical capital. Three types of housing conditions were observed with the fishermen of Payra river. About $52 \%$ of the fishermen had kacha houses which reflect the deplorable and distress condition of the fishing community. Rabbani (2007) revealed that $76.67 \%$ of housing structures were kacha, $15 \%$ were half semi-pucca and $8.33 \%$ were pucca. Ahmed (2002) found that $62 \%$ of kacha housing structure of farmers in Mymensingh area.

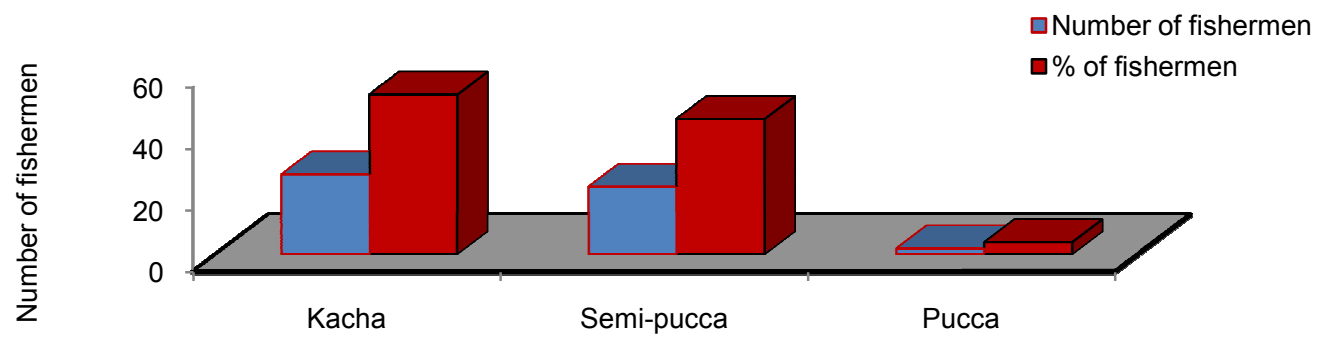

Figure 8 - Housing condition of riverine fishermen

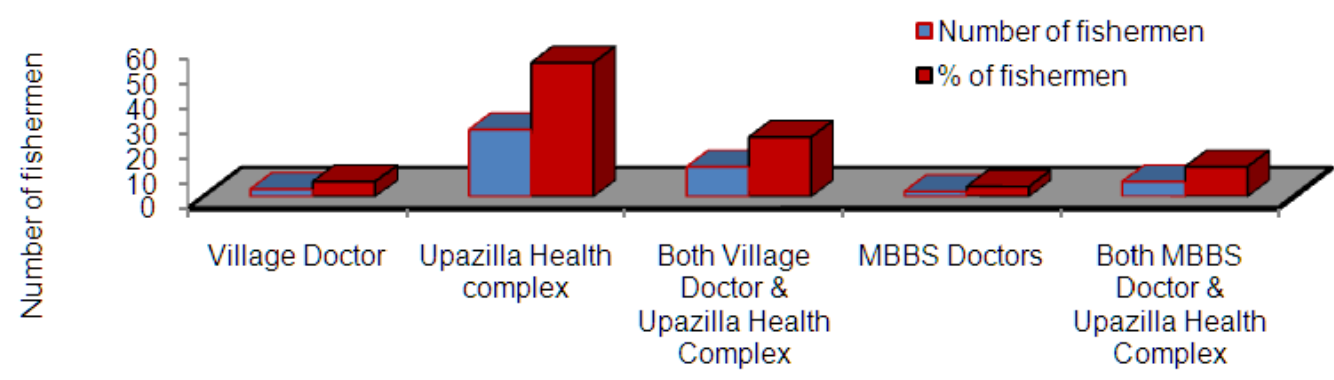

Figure 9 - Health service used by the riverine fishermen of Payra River

This study found that $54 \%$ of fishermen were dependent on upazila health complex, while $6 \%$ and $24 \%$ got health service from the village doctor and both village doctor \& upazila health complex respectively. Alam (2006) found in his study that only $42 \%$ of the farmers in 
the Mithapuqur upazila under the district Rangpur got the opportunities for medical care by MBBS doctor and Upazila health complex while the rest $58 \%$ was dependent on village doctor and others.

$92 \%$ of fishermen used boat to catch fish, but $8 \%$ of fishermen operated fishing gears and caught fish without boat. Most of the professional fishermen use boat to catching fish, but subsistence fishermen catch fish without boat. Jewel (2006) observed that $80 \%$ of fishermen used boat and $20 \%$ of fishermen caught fish without boat.

Financial capital. It was found that majority $(80 \%)$ of fishermen's main income source is fishing. Service and labor are the main occupation of $4 \%$ fishermen. Only $2 \%$ fishermen involve in agriculture and business. Rabbani (2007) observed that Jhaki jal fishermen earned $22.50 \%$ income from fishing and the lowest (11.09\%) average monthly income was found from fishing among the Khora jal fishermen.

Table 1 - Main source of income in the riverine fishermen

\begin{tabular}{|c|c|c|}
\hline Main income source & Average monthly income (Taka) & \% of total \\
\hline Fishing & 10410 & 27 \\
\hline Agriculture & 15000 & 20 \\
\hline Service & 11500 & 16 \\
\hline Labor & 9250 & 18 \\
\hline Business & 10000 & 27 \\
\hline
\end{tabular}

Other source of income. This study found that $28 \%$ fishermen are involved in agriculture as other occupation, $40 \%$ fishermen in labor, $8 \%$ in business, $2 \%$ in service and remained $10 \%$ in other occupation. During off season decrease catch rate and low income from fishing, majority of fishermen gave extra service such as other income source to fulfill their family demands.

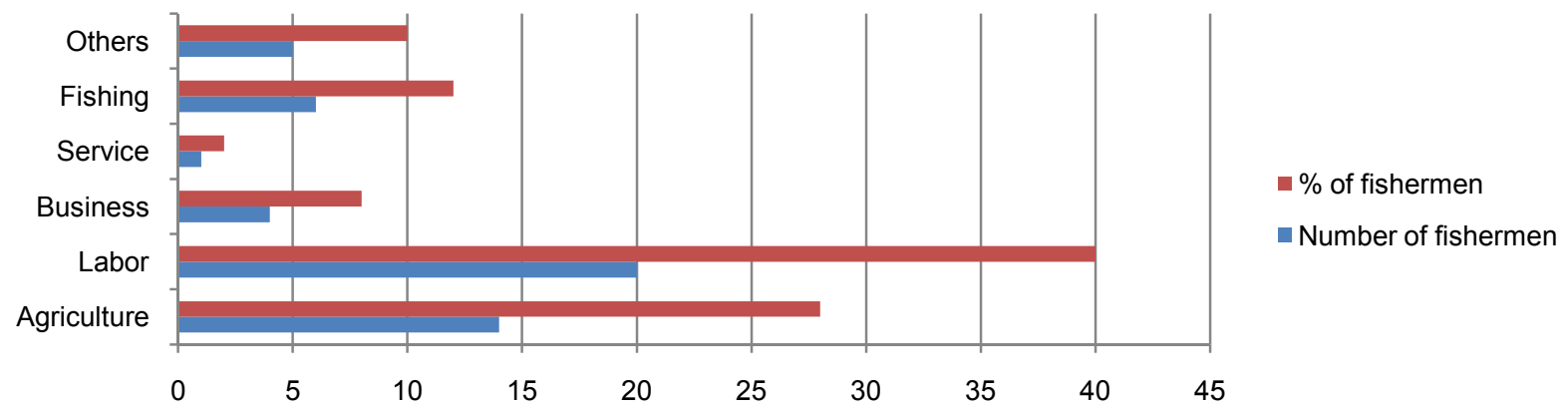

Figure 10 - Other sources of income of the riverine fishermen

Average monthly income. It was found that most of the fishermen had five types of main income source. When fishing is the main occupation, the average monthly income was found to be Tk. 10410.

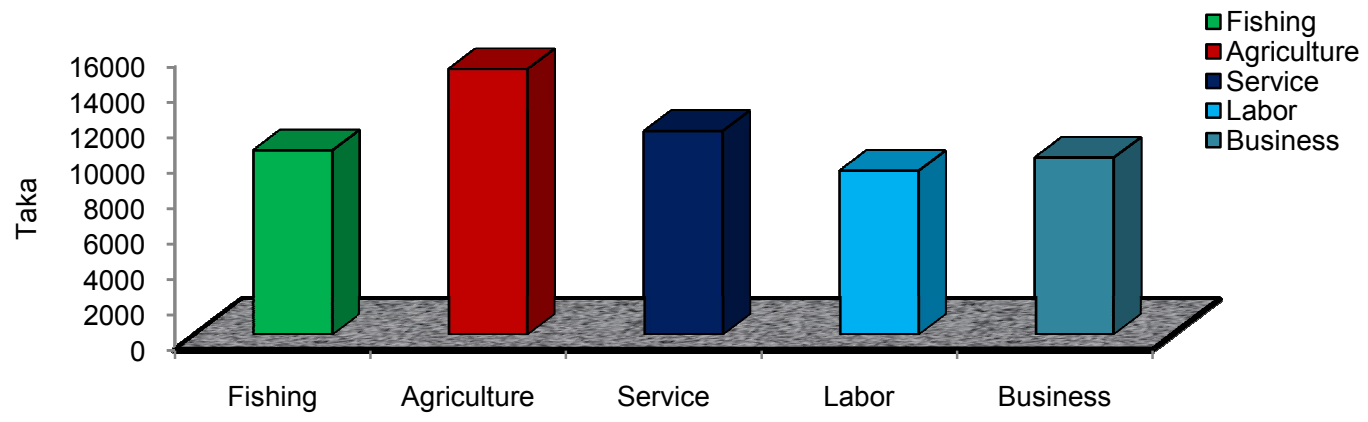

Figure 11 - Average monthly income of the riverine fishermen 
When agriculture, service, labor and business were the main occupation the average monthly income were Tk. 15000, 11500, 9250 and 10000 respectively. Hossain (2007) reported that the highest monthly average income was found in the seine net fishermen group and the lowest monthly average income was found in the push net fishermen group in the Mokesh beel, Gazipur.

Facilities received. This study revealed that most of the fishermen (about 90\%) receive government facilities. Only $10 \%$ of fishermen receive NGOs facilities. Hossain (2012) observed that $60 \%$ of fishermen received government facilities, $40 \%$ of received NGO's facilities.

\section{CONCLUSION}

Livelihood statuses of the riverine fishermen of Payra River were not satisfactory. The fishermen were deprived of many facilities. The education level was so poor and the affordability of education among fisherman is almost zero. So, NGO can play a vital role in here to support their education. Though, the Government is taking some important step by providing some sorts of extra providence during the ban season of the fishing but still this area needs more support to create a sustainable development of the fisherman. Moreover, health facilities must be improved in this area by the help of both NGO's and government. However, more innovative and extensive research are required to prepare better data-base information on biodiversity and fisheries with abundance problems aiming to develop practical rules and regulations.

\section{CONFLICT OF INTERESTS}

Authors clearly declare that they have no competing interests.

\section{ACKNOWLEDGEMENTS}

The author is also highly grateful to all fishermen of Payra River, Dumki Upazila, Patuakhali for their given information about their livelihood conditions. It was quite impossible to complete the research work without their help. The author humbly desires to acknowledge his heartfelt appreciation and profound thanks to all his friends, younger brothers and wellwishers specially, Mr. Al-Imran, Mr. Maknoon Hasan, Mr. Rezwanur Rahman, Mr. Sakhawat Hossain, Mr. Aminul Islam, Mr. Joydev Mistry, Mr. Depayon Bar and Mr. Barin Barai for their help during data collection and inspiration throughout the study period.

\section{REFERENCES}

1. Ahmed, N., (2002). Socio economic aspects of freshwater prawn culture development in Mymensingh, Bangladesh, A report prepared for ICLARM.

2. Alam, M. J., (2006). Status of fish farming and livelihood of the fish farmer in Mithapukur, Rangpur, MS Thesis, Department of Fisheries Management, BAU, Mymensingh. pp. 81.

3. Alam, M.F., Basha, M.A., (1995) Structure of cost and profitability of small scale riverine fishing in Bangladesh. J. Res. Prog., 9: 235-241.

4. Ali, M. M., Hossain, M. B., Minar, M. H., Rahman, S., Islam, M. S., (2014) SocioEconomic Aspects of the Fishermen of Lohalia River, Bangladesh. Middle-East Journal of Scientific Research, 19 (2): 191-195.

5. DoF, 2015. Department of Fisheries, Ministry of Fisheries and Livestock, Dhaka, Bangladesh.

6. Haider, D. K., (2002). Studies on the availability of small indigenous species (sis) of fishes and socio-economic condition of fisheries in two rice fields, MS Thesis, Department of Fisheries Management, BAU, Mymensingh. 
7. Hossain, S., Das, M., Hossain, M. S., Mimi, M. J., (2013). Socioeconomic condition of the fishermen in Jelepara under Pahartoli of Chittagong district. International Journal of Bio Research, 1:13-22.

8. Hossain, F. I., (2012). Study on the fisheries and socio-economic condition of fishermen of the Punarvhaba river in Sadar upazila, Dinajpur district, MS Thesis, Department of Fisheries Management, BAU, Mymensingh. pp. 59.

9. Hossain, M. M., (2007). Utilization pattern of Mokesh beel for livelihood of the local fishermen of Kaliachoir upazilla under Gazipur district, MS Thesis, Department of Aquaculture, BAU, Mymensingh. pp. 80.

10. Hossain, F. I., Miah, M. I., Hosen, M. H. A., Pervin, R., Haque, M. R., (2015) Study on the Socio-Economic Condition of Fishermen of the Punorvaba River under Sadar Upazila, Dinajpur. Journal of Fisheries 3(1): 239-244.

11. Islam, M. A., Hossain, M. M., Ahsan, M. E., Nahar, A. (2015). Status and current worries of fish diversity in the Payra river, Patuakhali, Bangladesh. International Journal of Fisheries and Aquatic Studies 2015; 2(3): 160-165.

12. IUCN, 2003. "Bangladesh. IUCN-The World Conservation Union." p. 294.

13. Jewel, M. A. S., (2006). Study on fishing gears and socio-economic conditions of fishermen of the Padma river, abstracts, 2nd Fisheries Conference and Research Fair 2006, Bangladesh Fisheries Forum (BFRF), 18-19 January 2006, Dhaka, Bangladesh. pp. 61.

14. Mahmud, T. A., (2007). Fish biodiversity and socioeconomic conditions of the fishing community in some selected areas of Chalan beel, MS Thesis, Department of Aquaculture, BAU, Mymensingh. pp. 27-53.

15. Mahmud, S., Ali., M. L., Ali., M. M., (2015) Present scenario on livelihood status of the fishermen in the paira river, southern Bangladesh: constraints and recommendation. International Journal of Fisheries and Aquatic Studies 2(4): 23-30.

16. Miah, M. A. R., (2004) Study on the community based fish catch assessment of Savar Khagorbari Zolkor beel in Pabna district, MS Thesis, Department of Fisheries Management, BAU, Mymensingh. pp. 28-50.

17. Pollnac, R. B., (1991). Social and cultural characteristics in small-scale fishery development. In: Cernea MM, editor. Putting people first. Sociological variables in rural development. New York: Published for the World Bank (by) Oxford University Press.

18. Rabbani, M. G., (2007). Fisheries and socio-economic condition of fishermen of Karatoa river, MS Thesis, Department of Fisheries Management, BAU, Mymensingh. pp. 85.

19. Shahjahan, M., (2000). Study on the fisheries and socio-economic conditions of the fisherman in the Jamuna river adjacent Dhunat upazilla under Bogra district, MS Thesis, Department of Fisheries Management, BAU, Mymensingh. p. 95. 